\title{
ВО КАНЦЕЛАРИЈАТА НА ДОКТОР ХАУС: ЛЕКЦИИ ПО АБДУКТИВНО РАСУДУВАњЕ
}

\section{Крайка содржина}

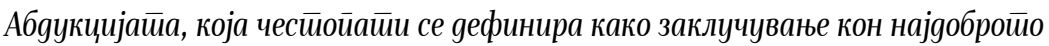

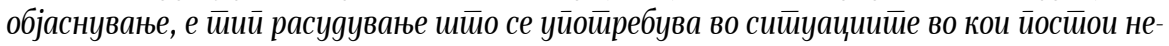

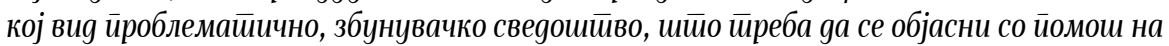

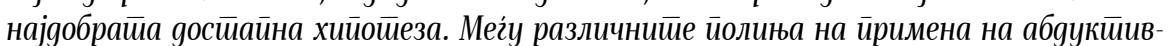

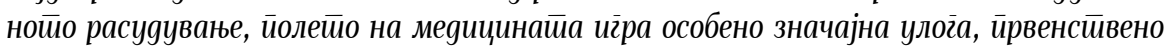

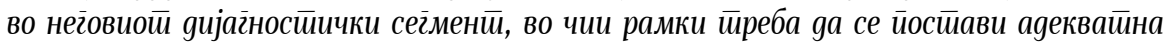

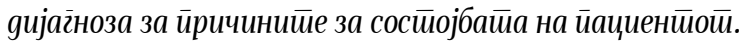

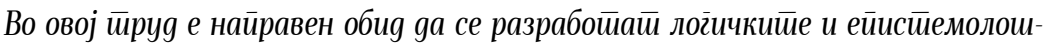

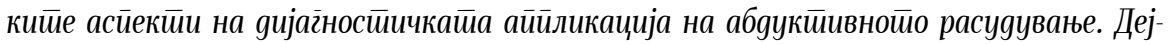

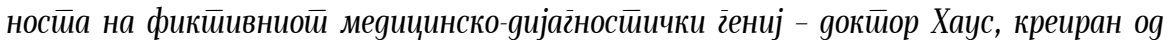

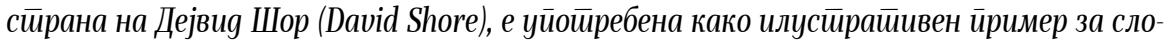

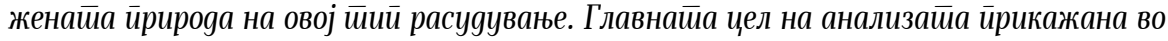

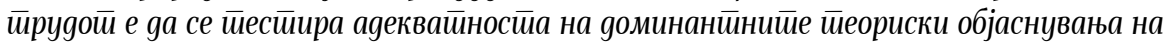

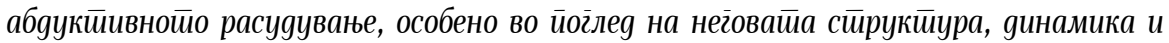

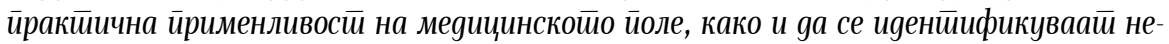

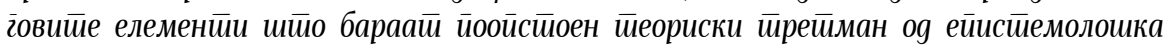
глеgна йочка.

Клучни зборови: АБДУКЦИЈА, ЗАКЛУЧУВАњЕ КОН НАЈДОБРОТО ОБЈАСНУВАЊЕ, ГЕНЕРИРАҢЕ НА ХИПОТЕЗИ, ОПРАВДУВАҢЕ НА ХИПОТЕЗИ, ДИЈАГНОСТИЧКО РАСУДУВАНЕ, ДОКТОР ХАУС

\section{Увод}

Кој е доктор Хаус? За пасионираните љубители на современите телевизиски играни серии со медицинска тематика, ова прашање, најверојатно, е реторичко. Кој од нив би можел да не го знае Грегори Хаус, уникатниот главен лик на американската телевизиска серија Хаус, брилијантно портретиран од страна на британскиот актер Хју Лори (Hugh Laurie)? За оние, пак, кои не се во таа мера запознаени

\footnotetext{
${ }^{1}$ Оваа серија првично е емитувана на мрежата Fox од 2004 до 2012 година; конципирањето на главниот лик првенствено е дело на Дејвид Шор (David Shore), кој, исто така, е и креатор на серијата (https://en.wikipedia.org/wiki/House_(TV_series)).
} 
со популарните продукти на американската ТВ-индустрија и немаат поим кој би можел да биде доктор Хаус, тој може да биде опишан како фиктивна личност, која, при хипотетичка средба со неа во реалниот живот, кај повеќето од нас би инспирирала силни, противречни чүвства.

Таквата реакција, всушност, би се должела не само на Хаусовиот исклучително тежок - мизантропски, циничен и нарцистички - карактер, туку, исто така, и на неговата професионална позиција. Имено, во споменатата телевизиска серија, Грегори Хаус раководи со тим дијагностичари како шеф на одделот за дијагностичка медицина во фиктивната Принстон-Плејнсборо клиничка болница во Њу Џерси. Тој е прикажан како медицински гениј чија мисија е да ги реши најтешките дијагностички случаи, претставувајќи еден вид „Шерлок Холмс“ на медицински план. Токму затоа, од гледна точка на пациентот, да се добие информацијата дека Хаус е назначен за негов или нејзин лекар претставува мешавина од лоши и добри вести. Од една страна, тоа значи не само дека случајот е речиси безнадежен, туку и дека пациентот ќе биде обврзан да соработува со лекар што има антисоцијална, непријатна, тешко поднослива структура на личноста, дополнително усложнета од неговата зависност од аналгетици. Но, од друга страна, тоа исто така значи дека ако постои и најмала шанса медицинската загатка да биде решена во рамките на временскиот период диктиран од напредувањето на болеста, Хаус, најверојатно, е единствениот што може да успее во тоа.

Но, во овој поглед, може легитимно да се постави следново прашање: кој е разлогот овој фасцинантен имагинарен лик да се направи објект на теориско интересирање, и тоа не од медицинска, туку од логичка, епистемолошка и, во поширока смисла, од филозофска гледна точка? Одговорот на ова прашање директно укажува на главната теориска мотивација на овој труд: во неговите рамки, ликот на Грегори Хаус е третиран како идеален пример на брилијантен „логичар во акција“. Неговата дејност уверливо го илустрира увидот дека доаѓањето до точна медицинска дијагноза, што е клучен фактор во успешното третирање на тешките случаи, не е работа само на механичко применување на општите дијагностички протоколи и на акумулираното медицинско знаење. Тоа е, првенствено, справување со сложен интелектуален предизвик што бара напорно, детално и длабинско размислување, кое е чувствително на спецификите на секој случај одделно и во кое примената на аналитичките и синтетичките способности, креативноста и сложените инференцијални процеси неразделно се преплетуваат.

Имајќи го предвид ова, во овој текст се застапува тезата дека начинот на кој Хаус ги решава медицинските загатки ги претставува, на мошне илустративен начин, главните логички механизми на еден специфичен вид расудување, познат како „абдуктивно расудување“, како и многубројните прашања што тоа ги отвора за логиката и епистемологијата како теориски дисциплини. Следствено, главната идеја на трудот се состои во обидот да се разлачат и да се анализираат спецификите на абдуктивното расудување, рефлектирани во начинот на кој Хаус им пристапува на најсложените медицински случаи. Целта на оваа анализа би се состоела во иденти- 
фикување на елементите на овој вид расудување што бараат поопстоен теориски третман, и во укажување на можните насоки за натамошно истражување на абдукцијата како значаен логички и епистемолошки инструмент. ${ }^{2}$

\section{1. Поимот и дострелот на абдуктивното расудување}

Иако во современата логичка и епистемолошка литература не постои универзално прифатена дефиниција на абдукцијата, во контекст на овој труд таа ќе биде сфатена како процес на расудување што се применува во ситуации во кои постои некој вид сведоштво (најчесто, сведоштво што има збунувачки или невообичаени одлики), кое треба да биде објаснето со помош на најдобрата хипотеза што е на располагање. Така, на пример, абдукцијата се определува како „облик на заклучување кој оди од податоците што опишуваат нешто кон хипотеза која најдобро ги објаснува тие податоци. Според тоа, абдукцијата е вид заклучување со кое се образуваат теории, односно интерпретативно заклучување“(Josephson and Josephson, 5). ${ }^{3}$

Од историска гледна точка, улогата на втемелувач на абдукцијата вообичаено му се припишува на американскиот прагматистички ориентиран филозоф и логичар Чарлс Сандерс Пирс (Charles Sanders Peirce), иако се смета дека и Аристотеловото сфаќање на поимот араgоge донекаде соодветствува на современите концепции за абдуктивното расудување (Aliseda, 28). Пирс се залага за проширување на традиционалната дихотомија на дедуктивните и индуктивните форми на расудувањето, воведувајќи ја абдукцијата како трет фундаментален тип расудување (cf. Карі$\tan , 1992)$. Според Пирс, абдукцијата е процес во кој „наидуваме на некоја мошне невообичаена околност, која би била објаснета преку претпоставката дека таа е случај на некое општо правило, и потоа ја прифаќаме таа претпоставка“ (СР, 2.624). Така, Пирсовиот генерален образец на абдуктивното заклучување е претставен на

\footnotetext{
${ }^{2}$ Иако, од методолошка гледна точка, оваа цел, исто така, би можела да се постигне и преку анализата на реални примери за примената на абдуктивното расудување на полето на медицината, тука доменот на фикцијата е намерно избран како своевидна теориска лабораторија за проучување на абдукцијата. Таквиот избор е мотивиран од согледбата дека имагинарната природа на дејството и ликовите во серијата дава поголема слобода на комбинирање на околностите и факторите што ги конституираат сложените медицински загатки и нивните решенија. Оваа фикционална природа овозможува полесно да се изолираат нивните базични логички елементи, и едновремено, уверливо ја нагласува релевантноста на тие елементи за една од најосновните човекови преокупации - сочувувањето на животот и на здравјето.

${ }^{3}$ Врз основа на оваа карактеристика, во современите истражувања абдукцијата честопати се третира како синонимна со заклучувањето кон најдоброто објаснување (Harman, 1965, Walton, 2005, Lipton, 2007). Сепак, едноставното изедначување на овие два поима не е универзално прифатено, поради разликувањето на абдукцијата сфатена како: 1) објаснувачко расудување при генерирањеӣо на хипотезите и 2) објаснувачко расудување при нивното ойравgување. Така, постојат гледишта дека единствено во второто од овие две значења абдукцијата може да се третира како заклучување кон најдоброто објаснување (Douven, 2017).
} 
следниов начин:

Регистриран е невообичаениот факт С.

Но доколку А би било вистинито, С би било очекувано.

Според тоа, постои разлог да се претпостави дека А е вистинито (СР, 5, 189).

Ова Пирсово сфаќање на абдукцијата ја нагласува невообичаената природа на фактите и околностите што го активираат применувањето на абдуктивните механизми. Според Аточа Алиседа (Aliseda, 47), новоста и аномаличноста на набљудуваните податоци функционираат како поттик за применување на абдуктивните процедури, укажувајќи на некој вид епистемичка тешкотија што треба да се отстрани. Сепак, во абдуктивната рамка, оваа цел не може да се постигне преку едноставно стекнување на ново знаење. Развивајќ ја оваа идеја, Џон Вудс ја опишува абдукцијата како специфичен вид одговор на проблемите создадени од незнаењето. Проблемите од овој вид се јавуваат кога некој дејствител се соочува со „епистемичка цел што не може да се постигне преку познавателните ресурси со кои тој располага во дадениот момент, или кои може лесно и навремено да ги обезбеди“ (Woods, 218). Според ова објаснување, абдукцијата се третира како начин на расудување што не го елиминира незнаењето; сепак, тоа не значи дека неговата цел е епистемичкиот дејствител да се држи во состојба на незнаење и пасивност. Напротив, абдукцијата е проактивен начин за справување со проблемите предизвикани од незнаењето, бидејќи таа „на дејствителот му нуди разумна основа за дејствување во присуство на неговото незнаење“ (Woods, 218). ${ }^{4}$

Ваквите приоди кон абдукцијата овозможуваат јасно да се идентификуваат некои од нејзините најзначајни логички карактеристики. Така, очигледно е дека, за разлика од дедуктивните, абдуктивните заклүчоци се немонотонични. Тоа значи дека во рамките на еден абдуктивен заклучок, додавањето нови премиси може да ги направи претходните конклузии невалидни, бидејќи абдуктивните конклузии имаат, во принцип, провизорен карактер. Тие го оспособуваат епистемичкиот дејствител да изведува отповикливи конклузии од некомплетни и/или противречни информации и, следствено, да не биде одвратен од дејствување поради невозможноста да дојде до дедуктивно валидни конклузии врз основа на таквите информации.

Имајќи ги предвид овие карактеристики, не е тешко да се објасни феноменот на „сеприсутност“ на абдукцијата, т.е. распространетоста на нејзините механизми во многу различни полиња, почнувајќи од секојдневното расудување, преку формирањето на филозофските и научните теории, па сѐ до толкувањето на јазичните феномени, кривичните истраги, правното расудување, вештачката интелигенција и други области (cf. Gonzalez and Haselager, 2005; Magnani, 2005, 2014; Neal, 2000; Pa-

\footnotetext{
${ }^{4}$ Вудс ја развива оваа концепција за абдукцијата во соработка со Дав Габеј (Dov Gabbay), па оттаму таа е позната и под името „GW-модел“.
} 
ul, 1993; Peng and Reggia, 1990; Poole, 1990; Sun, Finnie and Weber, 2005; Walton, 2005). Истражувањата во сите овие сфери отвораат голем број концептуални проблеми поврзани со абдуктивното расудување, како што се, на пример: односот на абдуктивното и индуктивното расудување како различни форми на недедуктивното заклучување; критериумите за формирање и евалуирање на прифатливите хипотези при објаснувањето на набљудуваните факти; присуството на дедуктивните елементи во извлекувањето на логичките последици од различните хипотези; класификацијата на абдуктивните заклучоци; нормативниот статус на абдуктивното расудување итн. Теориската, но и практичната важност на овие и на сродните проблеми е на специфичен начин одразена во функционирањето на абдукцијата на планот на медицинската дијагностика, која претставува едно од парадигматичните подрачја што можат да ни помогнат да ја разбереме суштината на абдуктивното расудување.

\section{2. Улогата на абдукцијата во медицинската дијагностика}

На полето на медицината, особено во нејзиниот дијагностички сегмент, абдукцијата игра особено значајна улога (Console and Torasso, 1991; Dragulinescu, 2016; Vertue and Haig, 2008; Ward and Haig, 1997). Тука, поттикот за апликација на абдуктивното расудување е комбинацијата на симптомите на пациентот, особено на наодите што покажуваат абнормални вредности. Поаѓјќи од таквото сведоштво, дијагностичкиот напор цели кон доаѓање до хипотеза што најдобро ги објаснува овие симптоми. Објаснувачките хипотези што се употребуваат во дијагностичкиот процес имаат карактер на „хипотези за дисфункционалноста“, бидејќи тие имаат цел да дојдат до прифатливи претпоставки за потеклото на дисфункционалноста манифестирана во симптомите на пациентот (Josephson and Josephson, 9). Од логичка гледна точка, нивното функционирање се вклопува во општиот образец на индуктивното заклучување: „Кога е дадено сведоштвото $E$ и потенцијалните објаснувања $H_{1}, \ldots, H_{n}$ на Е, ако $H_{i}$ го објаснува $E$ подобро од која било друга хипотеза, треба да се заклучи дека $H_{i}$ е поблиска до вистината отколку која било од другите хипотези“ (Douven, 2017). Применето на сферата на медицинската дијагностика, тоа би значело дека коректната дијагностичка конклузија би требало: 1) да ги објасни симптомите, 2) да биде прифатлива како потенцијално објаснување и 3) да биде значително подобра отколку алтернативните објаснувања (ibid.).

Тука би требало да се нагласи дека целиот процес на доаѓае до медицинска дијагностичка конклузија има сложена логичка структура, во која абдуктивните елементи се комбинирани со индуктивните и со дедуктивните елементи на различни стадиуми на дијагностичките процедури. Оваа структура е адекватно претставена во моделот „S - T“ („select and test“), развиен од Мањани и други автори, како епистемолошки модел на дијагностичкото расудување (Magnani, 2000; за неговата релација со Хемпеловиот (Hempel) хипотетичко-дедуктивен модел на научното paсудување, cf. op. cit., 21, 39). Целиот процес започнува со извесни набљудувани податоци, од кои се апстрахира клиничката евиденција што треба да се објасни. По- 
тоа, се врши почетно структурирање на дијагностичкиот простор преку процес на „селективна абдукција“, што резултира со доаѓање до множество од прифатливи дијагностички хипотези. Следниот чекор вклучува дедуктивно развивање на нивните консеквенции, и нивно тестирање преку споредување со достапните податоци за состојбата на пациентот, со цел да се зголеми прифатливоста на определена хипотеза или да се побијат сите хипотези освен една. Сепак, доколку очекуваните податоци не соодветствуваат со новодобиените податоци или ако во текот на првиот циклус се појават нови информации, претходниот дијагностички простор може да биде проширен со воведување нови хипотези, и да се иницира нов циклус (Magnani, 23-24).

Оваа комплексна, мултициклична природа на дијагностичкиот процес, се чини, е систематски рефлектирана во дејноста на нашиот (поточно, Шоровиот) фикционален медицински гениј, доктор Хаус. Општиот образец што, наспроти сите разлики помеѓ случаите третирани во секоја епизода од серијата, го претставува нивниот заеднички епистемолошки именител, всушност, може да се сведе на споменатата процедура „избери и тестирај“. Многубројните суптилности карактеристични за поединечните случаи ја нагласуваат специфичната логичка природа на абдуктивните дијагностички хипотези кои, давајќи му на лекарот „разумна основа за дејствување во присуство на неговото незнаење“ (Woods, supra) за реалната причина на болеста на пациентот, исто така, можат да го наведат на различни предвидливи или непредвидливи грешки. Така, во остатокот од трудов, ова тврдење ќа биде илустрирано со куса анализа на релевантните аспекти на еден од имагинарните случаи третирани од Хаус, во епизодата со филозофски мошне индикативно име „Окамовиот брич“.

\section{3. Хаусовите абдукции: Окамовиот брич и едноставноста на објаснувањето}

Со цел да се олесни анализата на епистемолошките аспекти на случајот третиран во оваа епизода (тука претставен на мошне поедноставен начин), ќе биде искористен образецот на доаѓањето до дијагностичка конклузија во пет чекори, опишан од Танер (Tanner) и Џозефсон (Josephson and Josephson, 10), кој ќе биде употребен како водич низ последователните етапи на дијагностичкото расудување на Хаус и на неговиот тим.

\section{1. Посииои наоg шиеио мора да се објасни.}

Во почетокот на епизодата се среќаваме со млад студент што е примен во болницата со необјаснив комплекс од симптоми: кашлица, исипување, болки во стомакот, мачнина, треска и низок крвен притисок што не реагира на примената инфузија. Овој невообичаен факт го активира дијагностичкиот абдуктивен процес, преку формулирање дијагностички хипотези што го извршува Хаусовиот тим. 


\section{2. Наоgой може gа се објасни на йовеќе начини.}

Во процесот на потрага по диференцијална дијагноза, колегите на Хаус формулираат неколку алтернативни хипотези. Така, како можни причини на симптомите на пациентот се наведуваат габична инфекција (absidia), артритис, алергија и карциноид. Во рамките на претходно споменатиот S-T модел, оваа фаза го претставува почетното „структурирање на дијагностичкиот простор“ преку неколку прелиминарни хипотези.

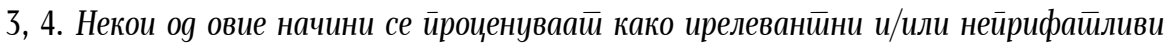

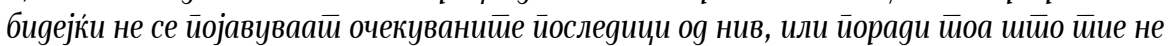

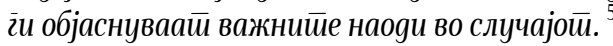

Сепак, во нивната дискусија, членовите на дијагностичкиот тим ја отфрлаат секоја од предложените дијагностички хипотези: габичната инфекција не би предизвикала исипување или кашлица, артритисот не би предизвикал проблеми со крвниот притисок, алергијата не би го објаснила појавувањето на стомачната болка. На сличен начин е елиминирана и хипотезата за карциноидот. Во овој стадиум од процесот, од епистемолошка гледна точка, дедуктивните елементи на дијагностичките процедури влегуваат во игра; се изведуваат логичките консеквенции од секоја хипотеза и се споредуваат со податоците од случајот, со цел да се зголеми или да се намали нивната почетна прифатливост. Идеалниот исход од овој процес би бил да се потврди една од прелиминарните хипотези и да се исклучат сите останати.

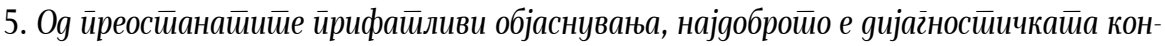
клузија.

Меѓутоа, на оваа точка, Хаусовата борба со комплицираниот случај започнува да отстапува од едноставниот, парадигматичен дијагностички образец. Така откако се заклучува дека „ниедна состојба не ги објаснува сите симптоми“ и се исклучуваат сите прелиминарни хипотези, не постои финална дијагностичка конклузија што би се квалификувала како најдобро објаснување на симптомите на пациентот. Но, лекарите како епистемички дејствители, исто така, се практични дејствители чија мисија е спасување на животот на пациентот; нивната блокираност од незнаењето за вистинската причина на болеста и непреземањето никакви практични мерки за лекување може него да го доведе во животна опасност. Затоа дијагностичкиот процес мора да продолжи со отворање нов циклус на генерирање и оправдување на хипотезите.

Следниот чекор на Хаус е да дејствува според хипотезата дека пациентот се бори со некој вид стомачна инфекција; следствено, тој му препишува антибиотици против можна сепса. За жал, антибиотиците само ја отежнуваат состојбата на пациентот: неговите бубрези откажуваат, додавајќ нов симптом на претходните. Тогаш, не прифаќајќи ја сугестијата на еден од неговите колеги дека состојбата на пациентот е предизвикана од ретка форма на срцева вирусна инфекција, Хаус ја из-

\footnotetext{
${ }^{5}$ Тука чекорите 3 и 4 од изворниот образец се интегрирани во еден единствен чекор.
} 
ложува хипотезата дека постои комбинација на две патолошки состојби (инфекција на синусите и хипотиреоза) што би ги покриле сите симптоми, и почнува третман за двете претпоставени болести. Сепак, оваа одлука е критикувана од страна на протагонистот на хипотезата за срцева инфекција, кој смета дека Хаусовата теорија дека пациентот симултано бил погоден од две сосем неповрзани болести е мошне неверојатна и оди наспроти принципот на „Окамовиот брич“ - наједноставното објаснување е најдобро ${ }^{6}$.

Тука, се среќаваме со үште еден контроверзен епистемолошки детаљ, поврзан со широко дискутираното теориско прашање за критериумите што една абдуктивна хипотеза мора да ги задоволи за да биде прифатлива. Уште во Пирсовиот третман на абдукцијата, беше потенцирана важноста на „Окамовиот брич“, кој Пирс го смета за најиздржана логичка максима во научното истражување (СР 5.60). Според сфаќањето инспирирано од оваа максима, една од најзначајните одлики на прифатливата хипотеза, освен нејзиниот објаснувачки капацитет и подложноста за тестирање, е нејзината логичка економичност или едноставност, сфатена како квалитет на содржење помал број независни фактори. Сепак, Хаус ја проблематизира идејата дека бројот на фактори вклучени во прелиминарното објаснување на некој медицински проблем е единствен критериум за неговата едноставност и, следствено, за неговата прифатливост. Всушност, тој тврди дека неговата хипотеза, заснована врз комбинација на две независни, но повообичаени болести, сепак, е поверојатна отколку хипотезата за вирусна срцева инфекција, базирана врз еден фактор, но со многу поретко јавување. Во неговиот уникатен стил, тој се подбива со приговорот на својот колега, поставувајќи го прашањето: „Зошто едно е поедноставно од две? Од понизок ранг е, поосамено е... но дали е поедноставно?“

Но дали оваа нова хипотеза изнесена од Хаус, како и третманот базиран врз неа, ќе бидат поуспешни од претходните? Во суштина, не. Лабораториските тестови извршени во меѓувреме покажуваат дека антибиотиците не се причина за откажувањето на бубрезите, и дека пациентот не страда од хипотиреоза; бројот на неговите бели крвни зрнца е мошне намален, и целиот одбранбен систем му откажува. Ова несовпаѓање помеѓу очекуваните и добиените податоци го принудува Хаус да истапи со нова хипотеза - дека пациентот, всушност, страда од труење со колхицин. Оваа хипотеза би ги објаснила сите негови симптоми, освен кашлицата. Главната разлика помеѓ оваа и сите претходни хипотези е тоа што таа воведува квалитативно нова претпоставка во објаснувањето на специфичноста на овој случај - човечката грешка! Хаусовата нова идеја е дека, всушност, како резултат на фармацевтска грешка, на пациентот наместо лек против кашлица, му бил даден лек против гихт - колхицин, кој го предизвикал труењето, а го оставил нетретиран примарниот симптом - кашлањето.

\footnotetext{
${ }^{6}$ Во формулацијата што му се припишува на Вилијам Окам, прочуениот схоластички филозоф и логичар, принципот гласи: „Entia non sunt multiplicanda praeter necessitatem“ („Ентитетите не треба да се умножуваат повеќе отколку што е неопходно“).
} 
Во сценариото на епизодата, првата проверка на коректноста на оваа хипотеза во аптеката не открива никаква грешка во дистрибуцијата на лекот против кашлица и Хаус е принуден да ја напушти својата теорија. Сепак, на крајот, по дополнителното влошување на состојбата на пациентот и појавувањето нови типични симптоми на труењето со колхицин, Хаус ја реафирмира својата хипотеза и започнува со третман против труењето, кој се покажува како успешен. Повторната проверка на аптеката покажува дека навистина постоела човечка грешка тешка за откривање, што резултирала со ненамерна замена на двата вида апчиња. Тоа дополнително ја потврдува теоријата на Хаус и сите делчиња на сложувалката најпосле доаѓаат на своето место. Ваквиот епилог одново ја евоцира ироничната формулација на „Окамовиот брич“, која Хаус ја изнесува во еден момент од епизодата; според него, наједноставното објаснување секогаш е дека некој ја „оплескал работата“(!)

\section{4. Можните извори на грешка во дијагностичката абдукција}

Намерната сложеност на овој случај, како и на другите имагинарни случаи со кои Хаус се справува овозможува да се тестира објаснувачката моќ на епистемолошките модели на дијагностичкото расудување не само кога станува збор за нормалното, успешно функционирање на абдуктивните механизми, туку, исто така, и во поглед на изворите на грешките што тие можат да ги генерираат. Така, во поглед на образецот на дијагностичкото заклучување во пет чекори, споменат во почетокот на овој оддел, Танер и Џозефсон укажуваат на фактот дека на секој од неговите чекори постои можност за појавување некој вид типична грешка. Така, кон (1), може да се јави грешка во почетните регистрирани податоци што довеле до прелиминарните хипотези; кон (2), дифренцијалната дијагностика може да не биде доволно широка; кон (3 и 4), некои хипотези неоправдано можат да бидат проценети како неприфатливи, или како да не ги објаснуваат значајните наоди, поради погрешни информации или недостаток на податоци (како што, всушност, беше случајот кога Хаус првпат ја фомулираше хипотезата за труење со колхицин како резултат на човечка грешка); кон (5), за дијагностичката конклузија може неоправдано да се смета дека ги објаснува наодите, т.е. дека е подобра отколку што навистина е, и на тој начин вистинскиот одговор може да биде потценет (Josephson and Josephson, 10-11).

Една посистематска и попродлабочена анализа на начинот на кој Хаус и неговите соработници во целата серија доаѓат до своите дијагностички конклузии би дала богат материјал за практична илустрација на сите погоре споменати начини на кои нештата можат да тргнат во погрешен правец при применувањето на абдуктивните обрасци на дијагностичкото расудување. Всушност, заплетот на секоја епизода од споменатата серија се врти околу борбата со неизвесноста, предизвикана од некомплетното и динамично сведоштво поврзано со патолошките медицински состојби и со нивниот третман. Оваа борба, водена низ последователните циклуси на генерирање и оправдување на дијагностичките хипотези, правење грешки и обиди тие да се идентификуваат и коригираат, бара целосна мобилизација, првен- 
ствено, на општите логички и епистемолошки ресурси на дијагностичарите, како претпоставка за максимизирање на ефектите на нивното професионално медицинско знаење. Токму затоа, сложената дејност на дијагностичкиот тим раководен од Хаус праќа мошне важна порака преку начинот на кој неговите членови се справуваат со најтешките медицински предизвици: сериозното, храбро, информирано, одговорно и имагинативно размислување - со еден збор висококвалитетното размислување - на полето на медицината може да спасува човечки животи, додека недостатокот од него може неповратно да уништи многу од нив.

\section{Заклучок}

Овој труд е инспириран од современите епистемолошки истражувања на абдукцијата како една од немонотоничните форми на расудување, употребена во ситуациите во кои има потреба да се оформи и да се оправда теорија што би објаснила определен комплекс од податоци, обично со неочекуван или аномаличен карактер. Полето на медицинската дијагностика е едно од најсложените и практично најзначајните полиња на примена на механизмите на абдуктивното расудување, што е отворено за понатамошно теориско истражување. Специфичната епистемолошка природа на медицинските дијагнози, кои се конструирани со некомплетни и динамични информации и кои вклучуваат различни процедури на расудување, се чини дека го фаворизира поширокото теориско гледиште за абдукцијата. Според ова гледиште, поимот за абдукцијата не би требало да биде поврзан исклучиво со процесот на оправдувањето на хипотезите, туку, исто така, би требало да биде способен теориски да ги третира повеќекратните процеси на нивно генерирање, критикување, прифаќање и споредбена евалуација. Во рамките на едно такво гледиште, прашањето за критериумите на почетната прифатливост и споредбениот квалитет на алтернативните дијагностички хипотези се особено предизвикувачки за понатамошно теориско истражување. 


\section{Литература}

Aliseda, A. (2006). Abductive reasoning: Logical investigations into discovery and explanation. Dordrecht: Springer.

Console, L. and Torasso, P. (1991). "On the co-operation between abductive and temporal reasoning in medical diagnosis”. Artificial Intelligence in Medicine, 3, pp. 291-311.

Douven, I. (2017). "Abduction", The Stanford Encyclopedia of Philosophy (Summer 2017 Edition), Edward N. Zalta (ed.) https://plato.stanford.edu/archives/sum2017/entries/abduction/ [Accessed 13 May 2018].

https://en.wikipedia.org/wiki/House_(TV_series) [Accessed 13 May 2018].

Dragulinescu, S. (2016). "Inference to the best explanation and mechanisms in medicine". Theoretical Medicine and Bioethics, 37(3), pp. 211-232. (doi 10.1007/s11017016-9365-9)

Gabbay, Dov M. and Kruse, R. (eds.) (2000). Abductive reasoning and learning. Dordrecht: Springer.

Gonzalez, M.E.Q and Haselager W.F.G. (2005). "Creativity: Surprise and abductive reasoning”. Semiotica, 153 (1/4), pp. 325-341.

Harman, G. (1965). "The inference to the best explanation”. The Philosophical Review, 74 (1), pp. 88-95.

Josephson, J.R. and Josephson, S.G. (1996). Abductive inference: Computation, philosophy, technology. Cambridge: Cambridge University Press.

Kapitan, T. (1992). "Peirce and the autonomy of abductive reasoning". Erkenntnis, 37, pp. 1-26.

Lipton, P. (2007). "Précis of Inference to the Best Explanation, $2^{\text {nd }}$ Edition”. Philosophy and Phenomenological Research, LXXIV (2), pp. 421-423.

Magnani, L. (2000). Abduction, Reason, and Science: Processes of Discovery and Explanation. New York/Boston/Dordrecht/London/Moscow: Kluwer Academic/Plenum Publishers.

Magnani, L. (2005). "An abductive theory of scientific reasoning”. Semiotica, 153 (1/4), pp. 261-286.

Magnani, L. (2014). "Abductive theory of cognition. The eco-cognitive model". RIFL / SFL, pp. 54-69. (doi10.4396/17SFL2014).

Neal, P. (2000). "Abduction and induction: a real distinction?". In Bunt, H. and Black, W. (eds.) Abduction, belief and context in dialogue: studies in computational pragmatics. Amsterdam: John Benjamins Publishing Company, pp. 381-389.

Paul, G. (1993). "Approaches to abductive reasoning: an overview". Artificial Intelligence Review, 7, pp. 109-152. 
Peirce, Ch. S. (1994). Collected papers of Charles Sanders Peirce. Charles Hartshorne, Ch., Weiss, P. and Burks, A. W. (eds.). Thoemmes Continuum.

Peng, Y. and Reggia, J.A. (1990). Abductive inference models for diagnostic problem-solving. New York: Springer.

Poole, D. (1990). "A methodology for using a default and abductive reasoning system". International Journal of Intelligent Systems, 5, pp. 521-548.

Sun, Zh., Finnie, G. and Weber K. (2005). "Abductive case-based reasoning”. International Journal of Intelligent Systems, 20, pp. 957-983.

Vertue, F.M. and Haig, B.D. (2008). "An Abductive Perspective on Clinical Reasoning and Case Formulation”. Journal of Clinical Psychology, 64 (9), pp. 1046 -1068.

Walton, D.N. (2005). Abductive reasoning. Alabama: University of Alabama Press.

Ward, T and Haig, B. (1997). "Abductive Reasoning and Clinical Assessment”. Australian Psychologist, 32, (2), pp. 93-100.

Woods, J. (2010). "Abduction and proof: A criminal paradox". In Gabbay, D. M., Canivez, P., Rahman, Sh. and Thiercelin, A. (eds.) Approaches to Legal Rationality. Dordrecht/Heidelberg/London/NewYork: Springer, pp. 217-238. 